\title{
Czteropłatkowa zastawka aortalna - rzadki wariant anatomiczny u 70-letniej pacjentki z objawami niewydolności serca
}

\author{
Quadricuspid aortic valve - rare anatomical variant \\ in 70-year-old patient with symptoms of heart failure
}

\author{
Ewa Szymczyk, Piotr Lipiec, Jarosław Damian Kasprzak
}

Katedra i Klinika Kardiologii Uniwersytetu Medycznego w Łodzi

Siedemdziesięcioletnia pacjentka z cichym szmerem rozkurczowym w polu osłuchiwania zastawki aortalnej została przyjęta do kliniki kardiologii z powodu znacznego pogorszenia tolerancji wysiłku od około roku (do III klasy NYHA; stężenie N-końcowego propetydu natriuretycznego typu B [NT-proBNP] 10966 pg/ml). W zapisie EKG przy przyjęciu stwierdzono migotanie przedsionków z częstością zespołów QRS 100-130/min, z ekstrasystolią komorową, bez zmian w zakresie odcinka ST. Echokardiogram wykazał powiększenie wszystkich jam serca, przerost mięśnia lewej komory z umiarkowaną dysfunkcją skurczową lewej komory (objętość końcoworozkurczowa $114 \mathrm{ml}$, końcowoskurczowa $59 \mathrm{ml}$, frakcja wyrzutowa 48\%) (ryc. 1). Wykazano istotną niedomykalność trójdzielną z zachowaną funkcją prawej komory oraz podwyższone ciśnienie skurczowe w tętnicy płucnej. Ze względu na znaczną otyłość (wskaźnik masy ciała [BMI] $46 \mathrm{~kg} / \mathrm{m}^{2}$ ) i ograniczenia obrazowania przezklatkowego wykonano przezprzełykowe badanie echokardiograficzne z wykorzystaniem trybu obrazowania trójwymiarowego. Potwierdzono w nim istotną niedomykalność trójdzielną oraz umiarkowaną niedomykalność mitralną. Uwidoczniono również niestwierdzaną w badaniu przezklatkowym czteropłatkową zastawkę aortalną (QAV, quadricuspid aortic valve) z umiarkowaną centralną niedomykalnością. Nieco sklerotyczne płatki o równej wielkości wykazywały prawidłową ruchomość z prawidłowym polem ujścia $3,2 \mathrm{~cm}^{2}$, bez patologicznego gradientu. Maksymalna szerokość aorty wynosiła $38 \mathrm{~mm}$. W uszku lewego przedsionka uwidoczniono niskoechogenną skrzeplinę. W trakcie hospitalizacji zmodyfikowano farmakoterapię pacjentki, uzyskując kontrolę ciśnienia tętniczego oraz istotne zmniejszenie objawów - zalecono kontrolne badanie echokardiograficzne za rok.

Przedstawiony opis dotyczy rzadkiego wariantu - QAV, która występuje u 0,013\% populacji ogólnej i w 1\% przypadków operowanych wad aortalnych [1, 2], co odpowiada częstości tego rozpoznania w pracowni echokardiografii autorów. Według podziału anatomicznego Hurwitza i Robertsa [3] u opisanej chorej występował najczęstszy, symetryczny typ A (lub typ I wg Jagannatha) [4]. Towarzyszące QAV wady obejmują anomalie ujść tętnic wieńcowych, przetrwały przewód tętniczy, zwężenia drogi odpływu lewej komory (LVOT) i niedomykalność mitralną. Częstość aortopatii i ryzyko dysekcji są dyskusyjne; u opisywanej chorej nie stwierdzono poszerzenia aorty.

Najczęstsza konsekwencja QAV to narastająca z wiekiem niedomykalność (zastawki u dzieci zwykle funkcjonują prawidłowo - kliniczna wada zazwyczaj ujawnia się po 5. dekadzie życia). Opisywane jest także zwiększone ryzyko zapalenia wsierdzia [5].
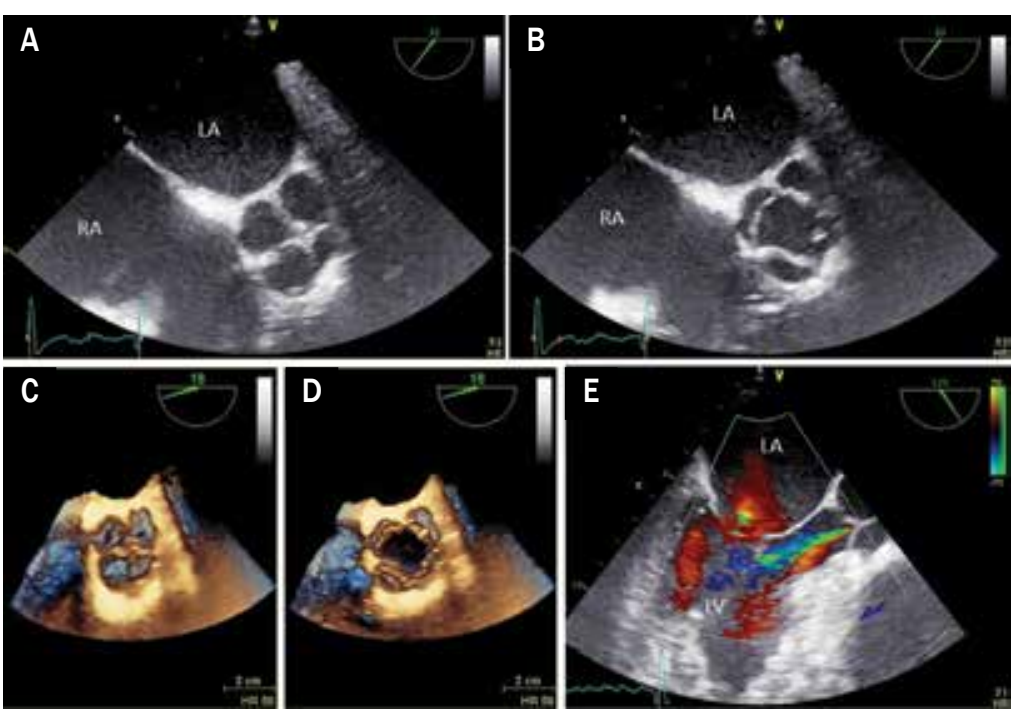

Rycina 1A-E. Echokardiografia przezprzełykowa przedstawiająca czteropłatkową zastawkę aortalną z centralną umiarkowaną niedomykalnością w fazie końcoworozkurczowej $(A, C)$ i śródskurczowej (B, D): A, B. Obrazowanie 2D w skali szarości; C, D. Obrazowanie 3D w czasie rzeczywistym - widok od strony aorty; E. Obrazowanie w trybie Dopplera kolorowego; LA - lewy przedsionek; RA - prawy przedsionek; $\mathrm{HR}$ - tętno; LV - lewa komora

Piśmiennictwo

1. Wierzbowska-Drabik K., Marcinkiewicz A., Kasprzak J.D. Preventive echocardiographic examination in athletes and workers - quadricuspid aortic valve and atrial septal aneurysm in a young basketball player. Int. J. Occup. Med. Environ. Health 2015; 28: 180-182.

2. Jedliński I., Jamrozek-Jedlińska M., Bugajski P. i wsp. Quadricuspid aortic valve. Kardiol. Pol. 2011; 69: 1084-1086.

3. Hurwitz L.E., Roberts W.C. Quadricuspid semilunar valve. Am. J. Cardiol. 1973; 31: 623-626.

4. Jagannath A.D., Johri A.M., Liberthson R. i wsp. Quadricuspid aortic valve: a report of 12 cases and a review of the literature. Echocardiography 2011; 28 : $1035-1040$.

5. Feldman B.J., Khandheria B.K., Warnes C.A. i wsp. Incidence, description and functional assessment of isolated quadricuspid aortic valves. Am. J. Cardiol. 1990; 65: 937-938.

Autor do korespondencji: dr n. med. Ewa Szymczyk, Katedra i Klinika Kardiologii, Uniwersytet Medyczny w Łodzi, Wojewódzki Szpital Specjalistyczny im. Władysława Biegańskiego, ul. Kniaziewicza 1/5, 91-347 Łódź, e-mail: eszymczyk@ptkardio.pl 